\title{
Specific-detection of alkaline phosphatase activity in individual species of marine phytoplankton
}

\author{
Haruo Yamaguchi, $^{* 1}$ Mineo Yamaguchi ${ }^{1} \&$ Masao Adachi ${ }^{2}$ \\ ${ }^{1}$ Harmful Phytoplankton Section, Harmful Algal Bloom Division, National Research Institute of Fisheries and Environment of Inland Sea, \\ Fisheries Research Agency, 2-17-5 Maruishi, Hatsukaichi, Hiroshima 739-0452, Japan \\ ${ }^{2}$ Laboratory of Aquatic Environmental Science, Faculty of Agriculture, Kochi University, Nankoku, Kochi 783-8502, Japan
}

Received 9 March 2006; Accepted 14 September 2006

\begin{abstract}
We evaluated the suitability of ELF-based assay (ELF: Enzyme-Labeled Fluorescence, Molecular Probes) as a tool for specific-detection of alkaline phosphatase (AP) activity in individual species of marine phytoplankton. Among 4 species of marine phytoplankton tested in the present culture experiments, the ELF-labeled cells of Karenia mikimotoi (Dinophyceae) and Skeletonema costatum (Bacillariophyceae) were simultaneously found with AP activity that was determined by using 4-methylumbelliferyl phosphate under the phosphorus-starved state but not found under the phosphorus-replete state. There were significant positive correlations between the percentage of ELF-labeled cells and AP activity of $K$. mikimotoi and of S. costatum. In contrast for Chattonella antiqua and Heterosigma akashiwo (Raphidophyceae) which do not produce AP, no ELF-labeled cells were found even under the phosphorusstarved state. Thus, ELF-based assay is considered to be useful for specific-detection of AP activity.
\end{abstract}

Key words: alkaline phosphatase, ELF, marine phytoplankton, Karenia mikimotoi, Skeletonema costatum

Orthophosphate $\left(\mathrm{PO}_{4}^{3-}\right)$ is considered to be the most biologically available form of phosphorus (Cembella et al. 1984). Recent evidence has indicated that many phytoplankton species can use dissolved organic phosphorus (DOP) compounds, such as sugar phosphates, nucleotide phosphates, and phospholipids (e.g., glycerophosphate). Alkaline phosphatase (AP) is a key enzyme responsible for the utilization of DOP (Kuenzler \& Perras 1965; Rivkin \& Swift 1980; Cembella et al. 1984; Dyhrman \& Palenik 1999; Yamaguchi et al. 2005). This scavenging enzyme typically appears to allow cells to acquire orthophosphate from AP-hydrolyzable phosphorus (APHP) under phosphorus-deficient conditions (Kuenzler \& Perras 1965; Cembella et al. 1984; Price \& Morel 1990). AP activity has been found in coastal waters (Kobori \& Taga 1979; Hirayama et al. 1989; Ammerman 1991; Nausch 1998; Hernández et al. 2000; Yamaguchi 2004b), and the activity has been shown to increase when the orthophosphate concentration in the waters decreases to less than $0.2 \mu \mathrm{M}$ (Nausch 1998; Yamaguchi et al. 2004b). As these AP activities are measured by the hydrolyzing ester of the substrates in the water, it is not possible to discern which phytoplankton species possess AP activity.

A fluorogenic substrate, ELF-97 (ELF: Enzyme-Labeled

\footnotetext{
* Corresponding author: Haruo Yamaguchi; E-mail, yharuo@kochi-u.ac.jp * Present address: Laboratory of Aquatic Environmental Science, Faculty of Agriculture, Kochi University, Nankoku, Kochi 783-8502, Japan
}

Fluorescence, Molecular Probes) was developed for detecting AP activity at a single-cell level (Huang et al. 1993; Larison et al. 1995). The substrate is enzymatically cleaved by the AP and the resulting product forms an intensely fluorescent precipitate at the site of the enzyme activity (González-Gil et al. 1998). In case of cultured Prorocentrum minimum (Pavillard) Schiller and Amphidinium carterae Hulburt, Isochrysis galbana Parke, and Trichodesmium erythraeum Ehrenberg ex Gomont phosphorus-starved cells were labeled with ELF, but phosphorus-replete cells were not (González-Gil et al. 1998; Dyhrman \& Palenik 1999; Dyhrman et al. 2002). These results suggest the possibility that the ELF-based assay can be used to monitor the phosphorus-state of marine phytoplankton at a single-species level. However, the relationship between ELF-labeling and AP activity of phytoplankton has not yet been fully elucidated. Thus, it is not clear if ELF-labeling is a useful marker for AP activity in individual phytoplankton species. Furthermore, the number of marine phytoplankton species which have been examined in studies using ELF-labeling is limited so far.

In the present study, we examined the relationships between ELF-labeling and AP activity of marine phytoplankton including AP-producing and non-AP-producing species under phosphorus-starved and -replete conditions. On the basis of the present results, we evaluated the suitability of the ELF-based assay as a useful tool for specific-detection of AP activity in individual species of marine phytoplankton. 
Four species of marine phytoplankton, Karenia mikimotoi (Miyake et Kominami ex Oda) G. Hansen et Moestrup (ax-2) (Dinophyceae), Skeletonema costatum (Greville) Cleve (NIES324) (Bacillariophyceae), Chattonella antiqua (Hada) Ono (NIES-1) and Heterosigma akashiwo (Hada) Hada ex Hara et Chihara (NIES-6) (Raphidophyceae) were used in the experiments. These strains were clonal and axenic. The NIES strains were obtained from the National Institute for Environmental Studies, Japan. Karenia mikimotoi and S. costatum produce AP under the phosphorus-starved state but $C$. antiqua and $H$. akashiwo have no ability to produce AP (Yamaguchi et al. 2004a; H. Yamaguchi unpublished data). The stock cultures were grown at $20^{\circ} \mathrm{C}$ under a $14 \mathrm{hr}$ light : $10 \mathrm{hr}$ dark photocycle. Light was provided by cool-white fluorescent illumination (120 $\mu \mathrm{mol}$ photons $\mathrm{m}^{-2} \mathrm{~s}^{-1}$ ). In all experiments, cultures of $K$. mikimotoi and C. antiqua were maintained in modified SWM3 medium based on natural seawater (Imai et al. 1996). Background inorganic and organic phosphorus concentration in the seawater was consistently less than $0.04 \mu \mathrm{M}$ and $0.24 \mu \mathrm{M}$, respectively. In addition, APHP was not found (detection limit: $0.02 \mu \mathrm{M}$ ). Cultures of $S$. costatum and $H$. akashiwo were maintained in $\mathrm{ASP}_{2}$-NTA medium (Provasoli et al. 1957) which contains $10 \%$ natural seawater in all experiments. The salinity and $\mathrm{pH}$ in all cultures were adjusted to $34 \mathrm{psu}$ and 7.8, respectively.

Stock cultures of $K$. mikimotoi, S. costatum, C. antiqua and H. akashiwo were inoculated into $300 \mathrm{~mL}$ flasks, each containing $100 \mathrm{~mL}$ of phosphate-replete $(+\mathrm{P})$ medium with an initial orthophosphate concentration of over $30 \mu \mathrm{M}$. These flasks were pre-incubated for 7 days for $S$. costatum or for 12 days for the others under the same conditions as for maintaining the stock cultures. After the pre-incubation, $c a$. $4-7 \mathrm{~mL}$ of the cell suspensions were inoculated into two 1-L flasks containing $600 \mathrm{~mL}+\mathrm{P}$ medium or phosphate-limited ( $-\mathrm{P}$; orthophosphate concentration was less than $1 \mu \mathrm{M}$ ) medium individually. Inoculum size of $K$. mikimotoi, $S$. costatum, $C$. antiqua, and $H$. akashiwo were adjusted to $c a .1 .0 \times 10^{2}$ cells $\mathrm{mL}^{-1}, 5.0 \times 10^{3}$ cells $\mathrm{mL}^{-1}, 1.0 \times 10^{2}$ cells $\mathrm{mL}^{-1}$, and $2.0 \times 10^{2}$ cells $\mathrm{mL}^{-1}$, respectively. The flasks were incubated under the same conditions as for the pre-incubation. Approximately $30-50 \mathrm{~mL}$ aliquots of the cultures were taken at 2 or 3 day intervals and were filtrated through a nuclepore filter $(0.8 \mu \mathrm{m}$, Whatman $)$ without pressure. Time-courses of cell density, AP activity in cell suspension and filtrate, orthophosphate concentration in filtrate, and percentage of ELF-labeled cells were determined by the following assays.

Cell number $(N)$ was directly counted by using a microscope. AP activity was measured based on the increase in fluorescence intensity of 4-methylumbelliferone (MUF) according to the method given in Yamaguchi et al. (2005). After being hydrolyzed by AP, nonfluorescent 4-methylumbelliferyl phosphate (MUF-P) produces the highly fluorescent molecule MUF (Hoppe 1983, 1993; Chróst 1991). AP activity in cell suspensions (wAP: whole AP activity) and $0.8 \mu \mathrm{m}$-filtrates (eAP: extracellular AP activity) was determined and cellular AP activity (cAP) of phytoplankton cell was calculated using the fol-

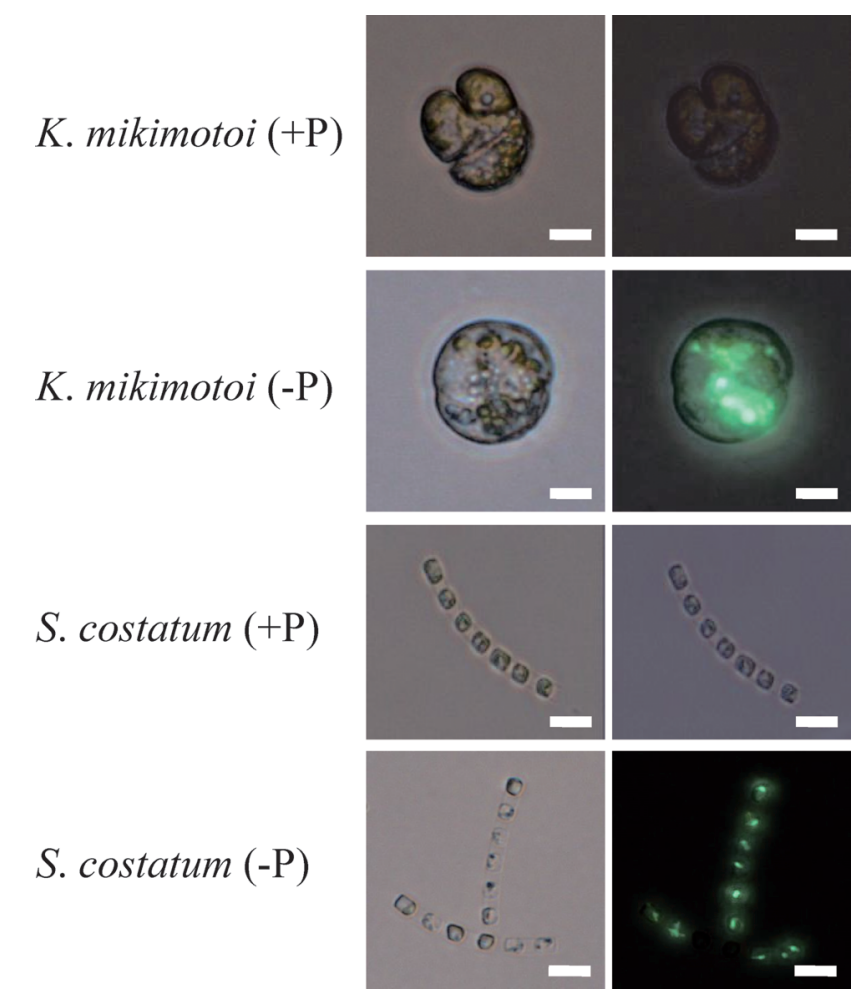

Fig. 1. Light (left panel) and epifluorescent (right panel) micrographs of Karenia mikimotoi and Skeletonema costatum cells in steady-state phase and growing in the phosphate-replete $(+\mathrm{P})$ or -limited $(-\mathrm{P})$ media on day 18 for $K$. mikimotoi $(+\mathrm{P})$, day 9 for K. mikimotoi $(-\mathrm{P})$, and day 6 for $S$. costatum $(+\mathrm{P})$ and $(-\mathrm{P})$. Scale bar shows $10 \mu \mathrm{m}$.

lowing equation: $\mathrm{cAP}=(\mathrm{wAP}-\mathrm{eAP}) / N(N$ : the total number of cells). Orthophosphate concentration in filtrates was analyzed by the method of Strickland \& Parsons (1972).

ELF-labeling assays were performed by using the procedure of Dyhrman \& Palenik (1999) without cell fixation. Because cell fixation by $70 \%$ ethanol (Dyhrman \& Palenik 1999) with ELF-labeling did not show significant differences in the percentage of ELF-labeled cells between fixed and non-fixed cells (data not shown). A $95-\mu \mathrm{L}$ aliquot of the cell suspension was incubated with $5 \mu \mathrm{L}$ of ELF-97 (Endogenous Phosphatase Detection Kit; Molecular Probes) in a $1.5 \mathrm{~mL}$ centrifuge tube for 2 hours at $25^{\circ} \mathrm{C}$ in the dark. Milli-Q water was used as the reagent control. The incubations were run in triplicate. In the ELF-labeling procedure, the cell suspension was concentrated by gentle filtration, if the cell number per tube was less than 100 cells. Concentrated cells were recovered by soaking the filter in $5 \mathrm{~mL}$ of the filtrates. ELF-stained cells were observed under an epifluorescence microscope with DAPI filter set (Rengefors et al. 2001). Percentage of ELF-positive cells to the total number of cells (percentage of ELF-labeled cells) was calculated based on the absence or presence of the fluorescent green precipitate in each cell.

ELF-labeled cells of Karenia mikimotoi and Skeletonema costatum were visualized at a single-cell level in the microscopic observations (Fig. 1). Green fluorescence from ELF 

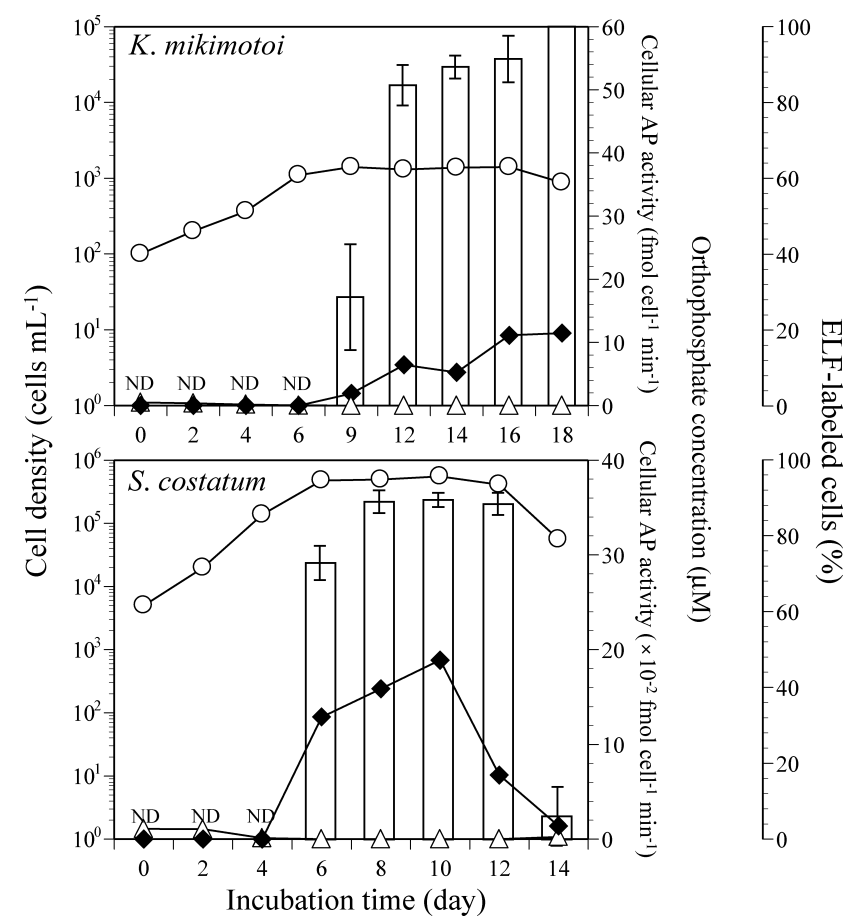

Fig. 2. Daily changes of cell density $(\bigcirc)$, orthophosphate concentration $(\triangle)$, cellular AP activity $(\diamond)$, and percentage of ELFlabeled cells (open bar) in the culture of Karenia mikimotoi (top) and Skeletonema costatum (bottom) growing in $-\mathrm{P}$ media. ND, ELF-labeled cell not detected. Bars show the standard deviation $(n=3)$.

was observed in the phosphorus-starved cells of $K$. mikimoto $i$ and $S$. costatum but not in the phosphorus-replete cells. In the case of Chattonella antiqua and Heterosigma akashiwo, no ELF-labeled cells were found regardless of the phosphorusstate. ELF-labeled cells of $K$. mikimotoi were found in $-\mathrm{P}$ medium on and after day 9 when orthophosphate concentration was less than $0.02 \mu \mathrm{M}$ (Fig. 2). The percentage of ELF-labeled cells was $29 \%$ on day 9 and increased to $100 \%$ on day 18 . AP activity was simultaneously found with ELF-labeled cells on day 9. After that, cellular AP activity increased to $11.5 \mathrm{fmol}$ cell $^{-1} \mathrm{~min}^{-1}$ on day 18. Both ELF-labeled cells (Fig. 1) and AP activity in $S$. costatum were first found on day 6 in $-\mathrm{P}$ medium (Fig. 2). Orthophosphate concentration on day 6 was less than $0.02 \mu \mathrm{M}$. The percentage of ELF-labeled cells was $73 \%$ on day 6 and was saturated at $90 \%$ on day 10 . After day 12 , the percentage rapidly decreased to $6.1 \%$ on day 14 . Cellular AP activity was found on and after day 6.

There were significant positive correlations between the percentage of ELF-labeled cells and cellular AP activity in $K$. mikimotoi $\left(r^{2}=0.793, n=6, p<0.02\right)$ and in $S$. costatum $\left(r^{2}=0.737, n=6, p<0.03\right)$ (Fig. 3). No ELF-labeled cells or AP activity of $C$. antiqua and $H$. akashiwo were found in either the phosphate-replete or -limited media (data not shown). These results indicate that the ELF-labeling is significantly correlated with the AP activity of the marine phytoplankton regardless of the activity level in each species. Therefore, ELF-

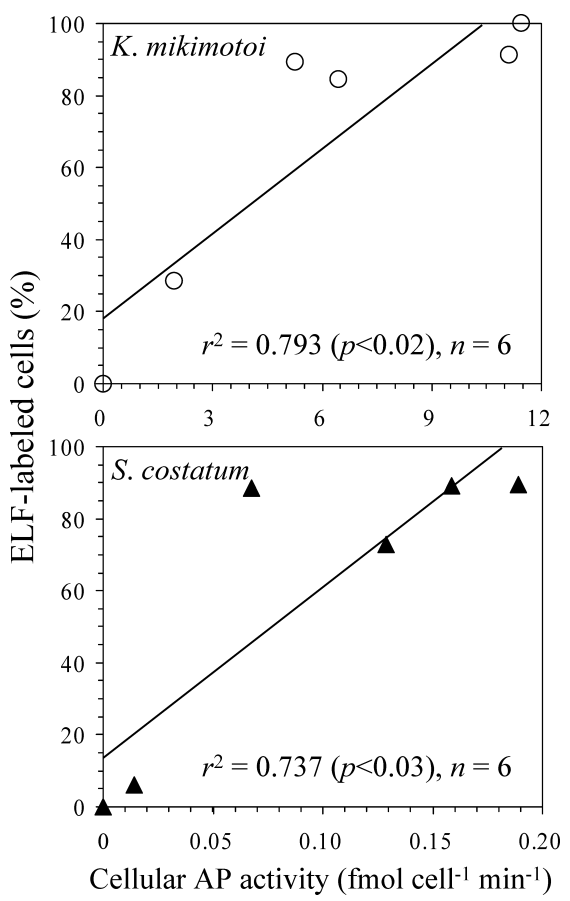

Fig. 3. Relationships between the percentage of ELF-labeled cells and cellular AP activity of Karenia mikimotoi (top) and Skeletonema costatum (bottom). The solid line represents the regression line for each species.

based assay is considered to be a promising tool for the detection of AP activity in individual species.

ELF-based assays have already been applied to field samples of phytoplankton in order to assess phosphorus-state at a single-species level (Dyhrman \& Palenik 1999, 2001; Rengefors et al. 2001, 2003; Štrojsová et al. 2003). Presence and absence of ELF-labeled cells may represent the phosphorusstarved and not starved state of the AP-producing species, respectively. However, the present experiment shows that the cells of non-AP-producing species (C. antiqua and $H$. akashiwo) were not labeled with ELF regardless of the phosphorus-state. Therefore, it is possible that if a particular species does not produce AP, their phosphorus-state could be undetected by an ELF-based assay (Rengefors et al. 2001).

In summary, the present results show that ELF-labeling reflects AP activity of AP-producing species in marine phytoplankton. Therefore, ELF-based assay is a suitable tool for the specific-detection of AP activity in individual species of marine phytoplankton. This tool will increase our ability to understand which species possess AP activity in diverse field populations of marine phytoplankton and how organic phosphorus contributes to the population dynamics of phytoplankton in coastal environments.

\section{References}

Ammerman JW (1991) Role of ecto-phosphohydrolases in phosphorus regeneration in estuarine and coastal ecosystems. In: Microbial Enzymes 
in Aquatic Environments (ed Chróst RJ). Springer-Verlag, New York, pp. 165-186.

Cembella AD, Antia NJ, Harrison PJ (1984) The utilization of inorganic and organic phosphorus compounds as nutrients by eukaryotic microalgae: a multidisciplinary perspective: Part I. CRC Crit Rev Microbiol 10: 317-391.

Chróst RJ (1991) Environmental control of the synthesis and activity of aquatic microbial ectoenzymes. In: Microbial Enzymes in Aquatic Environments (ed Chróst RJ). Springer-Verlag, New York, pp. 29-59.

Dyhrman ST, Palenik B (1999) Phosphate stress in cultures and field populations of the dinoflagellate Prorocentrum minimum detected by a single-cell alkaline phosphatase assay. Appl Environ Microbiol 65: 3205-3212.

Dyhrman ST, Palenik B (2001) A single-cell immunoassay for phosphate stress in the dinoflagellate Prorocentrum minimum (Dinophyceae). J Phycol 37: 400-410.

Dyhrman ST, Webb EA, Anderson DM, Moffett JW, Waterbury JB (2002) Cell-specific detection of phosphorus stress in Trichodesmium from the Western North Atlantic. Limnol Oceanogr 47: 1832-1836.

González-Gil S, Keafer BA, Jovine RVM, Aguilera A, Lu S, Anderson DM (1998) Detection and quantification of alkaline phosphatase in single cells of phosphorus-starved marine phytoplankton. Mar Ecol Prog Ser 164: 21-35.

Hernández I, Pérez-Pastor A, Pérez-Lloréns JL (2000) Ecological significance of phosphomonoesters and phosphomonoesterase activity in a small Mediterranean river and its estuary. Aquat Ecol 34: 107-117.

Hirayama K, Doma T, Hamamura N, Muramatsu, T (1989) Role of alkaline phosphatase activity in the growth of red tide organisms. In: Red Tides: Biology, Environmental Science, and Toxicology (eds Okaichi T, Anderson DM, Nemoto T). Elsevier, New York, pp. 317-320.

Hoppe H-G (1983) Significance of exoenzymatic activities in the ecology of brackish water: measurements by means of methylumbelliferyl-substrates. Mar Ecol Prog Ser 11: 299-308.

Hoppe H-G (1993) Use of fluorogenic model substrates for extracellular enzyme activity (EEA) measurement of bacteria. In: Handbook of Methods in Aquatic Microbial Ecology (eds Kemp PF, Sherr BF, Sherr EB, Cole JJ). Lewis Publishers, Boca Raton, pp. 423-431.

Huang Z, You W, Haugland RP, Paragas VB, Olson NA, Haugland RP (1993) A novel fluorogenic substrate for detecting alkaline phosphatase activity in situ. J Histochem Cytochem 41: 313-317.

Imai I, Itakura S, Matsuyama Y, Yamaguchi M (1996) Selenium requirement for growth of a novel red tide flagellate Chattonella verruculosa (Raphidophyceae) in culture. Fish Sci 62: 834-835.

Kobori H, Taga N (1979) Phosphatase activity and its role in the mineral- ization of organic phosphorus in coastal sea water. J Exp Mar Biol Ecol 36: 23-39.

Kuenzler EJ, Perras JP (1965) Phosphatases of marine algae. Biol Bull 128: 271-284.

Larison KD, BreMiller R, Wells KS, Clements I, Haugland RP (1995) Use of a new fluorogenic phosphatase substrate in immunohistochemical applications. J Histochem Cytochem 43: 77-83.

Nausch M (1998) Alkaline phosphatase activities and the relationship to inorganic phosphate in the Pomeranian Bight (southern Baltic Sea). Aquat Microb Ecol 16: 87-94.

Price N, Morel F (1990) Role of extracellular enzymatic reactions in natural waters. In: Aquatic Chemical Kinetics: Reaction Rates of Processes in Natural Waters (ed Stumm W). Wiley-Interscience, New York, pp. 235-258.

Provasoli L, McLaughlin JJA, Droop MR (1957) The development of artificial media for marine algae. Arch für Microbiol 25: 392-428.

Rengefors K, Pettersson K, Blenckner T, Anderson DM (2001) Speciesspecific alkaline phosphatase activity in freshwater spring phytoplankton: Application of a novel method. J Plankton Res 23: 435-443.

Rengefors K, Ruttenberg KC, Haupert CL, Taylor C, Howes BL, Anderson DM (2003) Experimental investigation of taxon-specific response of alkaline phosphatase activity in natural freshwater phytoplankton. Limnol Oceanogr 48: 1167-1175.

Rivkin RB, Swift E (1980) Characterization of alkaline phosphatase and organic phosphorus utilization in the oceanic dinoflagellate Pyrocystis noctiluca. Mar Biol 61: 1-8.

Strickland JDH, Parsons TR (1972) A Practical Handbook of Seawater Analysis. Bull Fish Res Bd Canada, Ottawa, 310 pp.

Štrojsová A, Vrba J, Nedoma J, Komárková J, Znachor P (2003) Seasonal study of extracellular phosphatase expression in the phytoplankton of a eutrophic reservoir. Europ J Phycol 38: 295-306.

Yamaguchi H, Nishijima T, Nishitani H, Fukami K, Adachi M (2004a) Organic phosphorus utilization and alkaline phosphatase production of 3 red tide phytoplankton. Nippon Suisan Gakkaishi 70: 123-130. (in Japanese with English abstract)

Yamaguchi H, Nishijima T, Oda A, Fukami K, Adachi M (2004b) Distribution and variation of alkaline phosphatase activity and phosphatase-hydrolyzable phosphorus in coastal seawaters. Nippon Suisan Gakkaishi 70: 333-342. (in Japanese with English abstract)

Yamaguchi H, Sakou H, Fukami K, Adachi M, Yamaguchi M, Nishijima T (2005) Utilization of organic phosphorus and production of alkaline phosphatase by the marine phytoplankton, Heterocapsa circularisquama, Fibrocapsa japonica and Chaetoceros ceratosporum. Plankton Biol Ecol 52: 67-75. 